NBER WORKING PAPER SERIES

\title{
HOW FINANCIALLY LITERATE ARE WOMEN? AN OVERVIEW AND NEW INSIGHTS
}

\author{
Tabea Bucher-Koenen \\ Annamaria Lusardi \\ Rob Alessie \\ Maarten van Rooij
}

Working Paper 20793

http://www.nber.org/papers/w20793

\author{
NATIONAL BUREAU OF ECONOMIC RESEARCH \\ 1050 Massachusetts Avenue \\ Cambridge, MA 02138 \\ December 2014
}

The authors wish to thank Ben Rump and Audrey Brown for excellent research and editorial assistance, and Mijke van den Broeke and Mario Padula for suggestions and comments. They are also grateful to participants at the FCAC-OECD conference on financial literacy held in Toronto in May 2011; the Netspar conference on Pension Communication and Choices held in The Hague in April 2012; the CeRP Conference, held in Turin in September 2012; and the European Economic Association Annual Meeting held in Toulouse, France, in August 2014 for many comments. Financial support from Netspar is gratefully acknowledged. Moreover, the authors gratefully acknowledge financial support from the European Investment Bank Institute through its EIBURS initiative. The findings, interpretations, and conclusions presented in this article are entirely those of the authors and should not be attributed in any manner to the European Investment Bank or its Institute, Netspar, the De Nederlandsche Bank, or the National Bureau of Economic Research.

NBER working papers are circulated for discussion and comment purposes. They have not been peerreviewed or been subject to the review by the NBER Board of Directors that accompanies official NBER publications.

(C) 2014 by Tabea Bucher-Koenen, Annamaria Lusardi, Rob Alessie, and Maarten van Rooij. All rights reserved. Short sections of text, not to exceed two paragraphs, may be quoted without explicit permission provided that full credit, including $\odot$ notice, is given to the source. 
How financially literate are women? An overview and new insights

Tabea Bucher-Koenen, Annamaria Lusardi, Rob Alessie, and Maarten van Rooij

NBER Working Paper No. 20793

December 2014

JEL No. D14,D91

\begin{abstract}
$\underline{\text { ABSTRACT }}$
We document strikingly similar gender differences in financial literacy across countries. When asked to answer questions that measure knowledge of basic financial concepts, women are less likely than men to answer correctly and more likely to indicate that they do not know the answer. In addition, women give themselves lower scores on financial literacy self-assessments than men. Both young and old women show low levels of financial literacy. Moreover, women for whom financial knowledge is likely to be very important—for example widows or single women—know little about concepts relevant for day-to-day financial decisions. Even women in favorable economic conditions are less financially knowledgeable than men. This is important because financial literacy has been linked to economic behavior, including retirement planning and wealth accumulation. Women live longer than men and are likely to spend time in widowhood. As a result, improving women's financial literacy is key to helping them prepare for retirement and promoting their financial security.
\end{abstract}

Tabea Bucher-Koenen

Max Planck Institute

for Social Law and Social Policy

Munich Center for the Economics of Aging

Amalienstraße 33, 80799 Munich, Germany

bucher-koenen@mea.mpisoc.mpg.de

Annamaria Lusardi

The George Washington University

School of Business

2201 G Street, NW

Duques Hall, Suite 450E

Washington, DC 20052

and NBER

alusardi@gwu.edu
Rob Alessie

University of Groningen

Department of Economics

P.O. Box 800

9700 AV Groningen

r.j.m.alessie@ rug.nl

Maarten van Rooij

Dutch Central Bank

P. O. Box 98

1000 AB Amsterdam

The Netherlands

M.C.J.van.Rooij@DNB.NL 


\section{Introduction}

With rapidly changing financial markets and increasing individual responsibility-in particular for retirement income-being able to make informed financial decisions has become of paramount importance. Yet, empirical research from various countries shows that many people know little about the concepts underlying saving and investment decisions. This may have substantial consequences for financial well-being, especially as it relates to the accumulation of retirement wealth (Lusardi and Mitchell, 2008; 2011a,b; 2014).

Not only is financial illiteracy widespread, but it is particularly severe among women. This is important because women tend to live longer than men; thus their savings needs are different. Women are likely to spend at least part of their retirement in widowhood. Evidence from the United States suggests that the death of a spouse is an important determinant of female oldage poverty (see Sevak, Weir, and Willis, 2003/2004; Weir and Willis, 2000). Moreover, women tend to have less attachment to the labor market, with interrupted careers because of childbearing and potentially fewer financial resources over the life cycle. With fewer available resources and higher life expectancies, women's financial security after retirement is potentially at risk. For example, Lusardi and Mitchell (2008) show that women are much less likely to plan and thus less likely to be prepared for their retirement than men.

In this paper we present evidence from financial literacy surveys around the world, with a special focus on women so as to provide insights into the financial literacy gender gap. We build on the work of Lusardi and Mitchell (2011b; 2014) that compares financial literacy in twelve countries, but we perform additional analyses on a subset of those countries. We use data from American, Dutch, and German surveys to evaluate levels of financial literacy via both objective and subjective measures. One advantage of using data from these countries is that we were able to coordinate the data collection effort and use information that is strictly comparable across countries. Moreover, we can make use of institutional characteristics, such as differences in East and West Germany, to gain additional insight into the roots of gender differences in financial literacy.

We confirm large gender differences in financial literacy in the United States, Germany, and the Netherlands. Not only are female respondents less likely to answer financial literacy questions correctly but they are also more likely to state that they do not know the answers to the questions. Gender gaps are large and strikingly similar across countries. The gender gap in financial literacy continues to persist even after taking into account marital status, education, income, and other socioeconomic characteristics. Moreover, we find a gender gap in financial literacy even among the young - this in spite of younger women having higher education levels and labor force participation. We also find that women are not likely to consult financial advisors to compensate for their lack of knowledge.

Gender differences occur not only in objective measures of financial literacy but also in selfreported financial literacy. When asked to assess their financial knowledge, women tend to give themselves lower scores than men. There is a mismatch between actual and self-assessed literacy and the size of that mismatch also differs between women and men. Not many women who answer the financial literacy questions correctly give themselves high scores while some of those who respond with at least one "do not know" answer rate their knowledge as high, suggesting that the "do not know" answer may—-to some extent-measure lack of confidence. 
We also show that financial literacy can be linked to behavior: Those who are more financially literate are more likely to plan for retirement, to invest in the stock market and pay attention to fees, and to borrow at low costs. Financial literacy can also be linked to greater financial well-being.

The structure of our paper is as follows. In section 2 we provide a summary of existing empirical results on the gender gap in financial literacy. We focus on results from the United States, the Netherlands, and Germany and show that the gap is very robust and does not go away even when we account for a set of demographic and economic characteristics. In section 3 we examine financial literacy gender gaps across age, marital status, household decisionmaking role, and geographic regions. In section 4 we examine self-assessed literacy, and in section 5 we study the relationship between financial advice and financial literacy. In section 6 , we discuss the links between financial literacy and financial behavior. We conclude with a discussion of our findings in section 7.

\section{Uncovering the gender gap in financial literacy}

While it is challenging to measure financial literacy, Lusardi and Mitchell (2011a) have designed a financial literacy module that has proven effective in measuring knowledge of simple but fundamental financial decision-making concepts and enabling comparisons of that knowledge across countries. The questions they developed-explained in more detail below-were initially designed for the US Health and Retirement Study and were subsequently incorporated into several other US surveys. These questions have since been fielded in more than twenty countries. ${ }^{1}$

The use of the same financial literacy questions across countries allows researchers to identify similarities in financial knowledge in distinct economic environments. Moreover, it enables identification of demographic groups that display low levels of knowledge. Women have emerged as a group that consistently shows low levels of financial literacy.

\subsection{Data sources and financial literacy}

We combine information taken from three nationally representative household surveys. For the United States, we use the 2009 National Financial Capability Study (NFCS). This survey was commissioned by the Financial Industry Regulatory Authority (FINRA) Investor Education Foundation in consultation with the Department of the Treasury and the President's Advisory Council on Financial Literacy. About 1,500 American adults were surveyed by telephone. ${ }^{2}$ For the Netherlands, we use De Nederlandsche Bank Household Panel (DHS). The DHS is an online panel of around 2,000 households run by CentERdata at Tilburg University. Data were collected in June $2010 .^{3}$ For Germany we use data from SAVE-a representative panel of German households. The panel has been run by the Munich Center for

\footnotetext{
${ }^{1}$ For an overview of the international comparison of financial literacy across twelve countries, see Lusardi and Mitchell (2011b; 2014). See Beckmann for a description of the financial literacy questions asked in ten Eastern European countries and see Boisclair, Lusardi, and Michaud (2014) for financial literacy questions asked in Canada.

${ }^{2}$ For more detail about these data, see Lusardi and Mitchell (2011c). While more recent data have become available, these data are most comparable with the Dutch and German data.

${ }^{3}$ For details about the data set and findings about financial literacy, see Alessie, Van Rooij, and Lusardi (2011a and b) and Van Rooij, Lusardi, and Alessie (2011a).
} 
the Economics of Aging (MEA) since 2001. In 2009 about 2,200 households participated. Respondents fill in a paper-and-pencil questionnaire. ${ }^{4}$

To evaluate financial literacy, respondents were asked three simple questions covering fundamental concepts of economics and finance, expressed in everyday terms, that require simple interest rate calculations and an understanding of the workings of inflation and risk diversification. ${ }^{5}$ These questions were the same across the three countries. The exact wording of the questions is as follows:

1) Suppose you had $\$ 100$ in a savings account and the interest rate was $2 \%$ per year. After 5 years, how much do you think you would have in the account if you left the money to grow $?^{6}$

More than \$102; Exactly \$102; Less than \$102; Do not know; Refuse to answer.

2) Imagine that the interest rate on your savings account was $1 \%$ per year and inflation was $2 \%$ per year. After 1 year, how much would you be able to buy with the money in this account?

More than today; Exactly the same; Less than today; Do not know; Refuse to answer.

3) Please tell me whether this statement is true or false. "Buying a single company's stock usually provides a safer return than a stock mutual fund."

True; False; Do not know; Refuse to answer

The first two questions measure whether respondents have a basic understanding of interest rates and inflation, which are economic concepts at the basis of financial decision-making. The third question evaluates knowledge of risk diversification, a more sophisticated concept that allows researchers to differentiate respondents across levels of financial literacy. Below we discuss the findings for the United States, the Netherlands, and Germany.

\subsection{The gender gap in financial literacy}

In Table 1a, we use data from the 2009 NFCS to describe the differences in financial literacy in the population and between women and men in the United States. Overall, financial literacy is rather low. A large fraction of Americans lack knowledge of simple financial concepts. For example, less than half of respondents correctly answered the question about interest rates and inflation and only one-third were able to correctly answer all three questions. Most important, women are much less likely to correctly answer the financial literacy questions than men; for each question, the proportion of correct answers was lower among women than men. For example, while $55 \%$ of men correctly answered the two questions about interest rates and inflation, only $38 \%$ of women did so. Moreover, while $38 \%$ of men correctly answered all three questions, only $22 \%$ of women did so. There is another important and notable gender difference in the responses to these questions. Women are much more likely than men to indicate that they do not know the answer to the questions. ${ }^{7}$ The proportion of "do not know" responses was particularly high on the risk diversification question; as many as $41 \%$ of

\footnotetext{
${ }^{4}$ For more details about SAVE see Börsch-Supan et al. (2009); for more information about financial literacy in SAVE, see Bucher-Koenen and Lusardi (2011).

${ }_{6}^{5}$ See Lusardi and Mitchell (2011a,b) for more detail on the measurement of financial literacy.

${ }^{6}$ Values in the US survey are expressed in dollars; values in the Dutch and German surveys are expressed in euros.

${ }^{7}$ The percentage of respondents who refused to answer the financial literacy questions was very small: about $1 \%$ for any one of the three questions.
} 
women indicated that they did not know whether a single company stock is riskier than a stock mutual fund. Moreover, half of women gave at least one "do not know" response to the three financial literacy questions.

(Table 1 about here)

Results for the Netherlands are reported in Table 1b. The findings are rather similar to those from the United States. While the proportion of correct answers is a little higher in the Netherlands than in the United States, financial literacy is not widespread among the Dutch population either. About $73 \%$ of respondents correctly answered the questions about interest rates and inflation, but less than half of respondents in the sample (45\%) were able to correctly answer all three questions. Most important, the Dutch data as well show a gender gap in financial literacy. Women are less likely to correctly answer the financial literacy questions. Moreover, as in the United States, women in the Netherlands are much more likely to indicate that they do not know the answer to the questions. While $38 \%$ of men gave at least one "do not know" response to the three questions, $46 \%$ of women answer with at least one "do not know."

German respondents' answers to the three questions are displayed in Table 1c. ${ }^{8}$ Findings are again very similar to those reported above. While about $70 \%$ of respondents correctly answered the questions about interest rates and inflation, only about half of the sample answered all three questions correctly. Moreover, women performed significantly worse than men. Compared to male respondents, women were equally likely to give correct answers to the interest rate question but were significantly less likely to correctly answer the inflation and risk diversification questions. About $60 \%$ of male respondents correctly answered all questions, compared to $48 \%$ of female respondents. Again, we find that women are disproportionately more likely to indicate that they do not know the answer. About $30 \%$ of male respondents and more than $43 \%$ of female respondents had at least one "do not know" response.

Comparing the gender gap in financial literacy among the United States, the Netherlands, and Germany reveals a striking similarity across the three countries. ${ }^{9}$ In all three countries, women were disproportionately more likely than men to state that they do not know the answer to a financial literacy question, in particular when considering the risk diversification question.

Very similar differences in financial literacy between men and women have been found in Sweden (Almenberg and Säve-Söderbergh, 2011), New Zealand (Crossan, Feslier, and Hurnard, 2011), Italy (Fornero and Monticone, 2011), Japan (Sekita, 2011), Australia (Agnew, Bateman, and Thorp, 2013), France (Arrondel, Debbich, and Savignac, 2013), and Switzerland (Brown and Graf, 2013). In all of these countries, women are not only less likely to correctly answer the three financial literacy questions but they are more likely to indicate

\footnotetext{
${ }^{8}$ In the German case, it is not possible to differentiate between "do not know" and "refuse to answer" responses, but in comparable surveys where it is possible to differentiate, the proportion refusing to answer is very low.

${ }^{9}$ When comparing results across countries one has to keep in mind that the design of the surveys in the three countries was different: in the United States, a telephone interview was conducted; in the Netherlands, respondents completed an online questionnaire; and in Germany, the questionnaire was in paper-and-pencil format. Thus, the gender gap holds across survey formats.
} 
that they do not know the answer to the financial literacy questions. Thus, we see a consistent pattern of responses across countries.

Russia and Romania provide interesting exceptions to the pattern. Klapper and Panos (2011) and Beckmann (2013) report no pronounced gender difference in the proportion of correct responses to the financial literacy questions in Russia and Romania, respectively. In general, the level of financial literacy is very low in these countries, with Russian and Romanian men and women appearing to know equally little. However, as in the countries previously mentioned, there is a significant gender difference in the number of "do not know" responses to all questions. In both Russia and Romania, women are much more likely than men to indicate that they do not know the answer to the financial literacy questions.

The gender gap in financial literacy is also evident when using a larger set of questions (up to 18) that assess understanding of both simple and complex financial concepts among Dutch, American, and German respondents (see van Rooij, Lusardi, and Alessie, 2011a; Lusardi and Mitchell, 2009; and Bucher-Koenen, 2011, respectively). Responses to this broader set of questions confirm the general prevalence of and the gender-specific differences in "do not know" answers. For every question in this additional set, women were significantly more likely than men to indicate that they do not know the answer to the questions. Moreover, the proportion of "do not know" answers is quite high, in particular for complex questions. For example, in Germany more than $40 \%$ of women stated that they do not know the answer to questions about the function of the stock market and $56 \%$ do not know the answer to questions about the workings of mutual funds. Thus, the pattern of responses we find for the three basic financial literacy questions mentioned above is replicated when considering a wider and more sophisticated set of questions.

Gender differences in financial literacy are also found in surveys covering different age groups. For example, Lusardi, Mitchell, and Curto (2014) examined financial literacy among an older cohort of respondents in the 2008 American Health and Retirement Study (HRS). They find that among American respondents over age 50, women know substantially less than men about complex aspects of investment and finance, and they perform less well on complex calculations. Because older women are more inclined to reply that they "do not know" the answer to the financial literacy questions, they are more likely to be classified among those with low literacy. These results are in line with results from an earlier examination of financial literacy among baby boomers using 2004 HRS data (Lusardi and Mitchell, 2007).

Gender disparities in financial literacy are also found in studies that use different measures of financial literacy. Earlier papers, mainly based on surveys in the United States, find a large gap in financial literacy between men and women (Hogarth and Hilgert, 2002; Hilgert, Hogarth, and Beverly, 2003). Gender differences also occur in other samples that cover specific subgroups of the population, such as those by Moore (2003), Mandell (2004), Agnew and Szykman (2005), and Agnew et al. (2008).

The gender gap in financial literacy does not seem to be domain specific. Lusardi and Tufano $(2009 \mathrm{a}, \mathrm{b})$ investigate debt literacy and find large differences between men and women: in some cases the share of women who gave correct answers was about 20 percentage points below the share of men. They also find that the gender gap in debt literacy applies for all age groups. Hung, Parker, and Yoong (2009) compare various financial literacy measures on the basis of data from the American Life Panel. They find that the gender disparity is persistent over time and across measurement methodologies. 
Overall there is compelling and robust evidence of a gender gap in financial literacy across countries with different financial market development and institutional set up. The difference between women and men is strikingly similar across countries.

\subsection{Is the gender gap real?}

Financial literacy is closely linked to demographic characteristics such as marital status, age, education, and income (see Lusardi and Mitchell, 2011b; 2014). So far, we have considered differences between women and men. But do these differences hold up when we account for differences in demographic and economic characteristics between women and men? In Tables 2 and 3, we report a set of multivariate regressions using data from the United States, the Netherlands, and Germany. ${ }^{10}$ In Table 2 the dependent variable is a dummy variable equal to 1 for respondents who answered all three financial literacy questions correctly. In Table 3 the dependent variable is a dummy equal to 1 if a respondent has at least one "do not know" response.

\section{(Table 2 about here)}

In each regression, we add a female dummy and, additionally, a set of controls that could account for the gender gap in financial literacy. We first note that the largest gender gap is in the Netherlands; Dutch women are 20 percentage points less likely than Dutch men to answer all three financial literacy questions correctly. American women are about 16 percentage points less likely than American men to give three correct answers, while German women are 12 percentage points less likely than German men to give correct answers to all three questions. In specifications 2 and 3 we add information on marital status and age. The gender effect decreases only slightly when controlling for these variables. In specification 4, we also add education dummies. Finally, we add income dummies. Controlling for these demographic characteristics hardly changes the gender gap among American respondents. American women are still about 14 percentage points less likely to give three correct answers. In the Netherlands the gender gap reduces by about 9 percentage points. Income differences between men and women seem responsible for about half of the gender gap among Dutch respondents. In Germany the gender gap reduces to half of the original difference mainly as a result of accounting for differences in education levels between men and women. Though marital status, age, education, and income can explain part of the gender gap in financial literacy, they do not explain it fully. Even after controlling for demographic and economic characteristics, women are less likely to answer all three financial literacy questions correctly.

We report similar findings when turning to the probability of respondents answering at least one question with "do not know" (Table 3). Without taking account of covariates, women in all three countries are between 13 and 17 percentage points more likely to reply with "do not know." After considering the same covariates as before, the gender gap diminishes but remains statistically significant. Across countries and even after accounting for economic and demographic characteristics, women are much more likely to state that they do not know the answer to the financial literacy questions.

(Table 3 about here)

\footnotetext{
${ }^{10}$ We are not using an Oaxaca-Blinder decomposition because, when running separate regressions for men and women, we did not reject equality of the coefficient estimates. Therefore no decomposition is called for.
} 
These results are in line with the findings by Fonseca et al. (2010) that covariates such as education, income, and marital status explain about $25 \%$ of the observed gender gap in financial literacy in the US. Thus, even though the gender gap can be partly explained by differences in socioeconomic characteristics between men and women, a large difference remains unexplained.

\section{Zooming in on financial literacy}

\subsection{The gender gap across age}

Having established that the gender gap in financial literacy is large across countries and does not go away even after we account for many demographic and economic characteristics, we turn next to examining the gap more closely and studying specific subgroups of the population to gain additional insight.

We first investigate financial literacy across different age groups. Women, especially older women, may be less financially literate than men because of traditional societal roles. Older generations of women are more likely to have stayed home to care for children and less likely to have engaged in the workforce where they might have dealt with financial decisions or to have discussed finances with colleagues, family, and friends. Today's younger generations of women are more likely to participate in the labor market, to be educated (for example, to have a college degree), and to move away from traditional societal roles. By examining data from three countries, we can determine whether similarities in financial literacy hold true across different institutional frameworks.

In Figures 1A-1C, we compare performance on the financial literacy questions of female and male respondents in different age groups. In general the age pattern of responses to the financial literacy questions for both men and women is in line with other studies that have argued that financial expertise shows a reverse U-shaped pattern over age (see Agarwal et al., 2009). ${ }^{11}$ In the United States, the Netherlands, and Germany, financial literacy is rather low among the young, but is lower among young women than young men. Thus, gender differences in financial literacy are present from the start of the life cycle in all three countries. While we cannot infer cohort patterns from a single cross-section, a look across the surveyed age groups suggests that gender differences in financial literacy continue to be pervasive among today's young people. This is worrisome because young people have to make many important financial decisions-from whether and how much to invest in education to dealing with credit cards and other debt to contributing to retirement accountsand women seem less equipped than men to effectively do so.

(Figures 1A-1C about here)

Other surveys find similar results. For example, using the same financial literacy questions, Lusardi, Mitchell, and Curto (2010) documented a gender difference in financial literacy among young adults (age 23 to 28) in the United States. Interestingly, the difference holds true even at high levels of education. For example, female respondents with a college degree are 13 percentage points less likely to give correct responses to the financial literacy questions than young males with a college degree (Lusardi, Mitchell, and Curto, 2010). Similarly, Goldsmith and Goldsmith (1997), Chen and Volpe (1998 and 2002), and Ford and Kent

\footnotetext{
${ }^{11}$ In a single cross section, we cannot differentiate age from cohort effects, but our interest is on the young and the old.
} 
(2010) found large differences in financial literacy between male and female college students. Other papers provide additional insight. For example, according to Chen and Volpe (2002), female college students are less enthusiastic about financial topics, less confident, and less willing to acquire financial skills. Moreover, Mandell (2008) found substantial gender differences in financial literacy among high school students; thus gender differences exist even beyond the age groups we have considered in our analysis.

Women's lack of financial literacy is found even among respondents with high levels of education. Mahdavi and Horton (2012) analyze the financial knowledge of alumnae from an elite female college in the United States. They report that financial literacy is low, even in this special group of women. In other words, even very well-educated women who are likely to have well-educated peers are not particularly financially literate, which could imply that women acquire financial literacy differently than do men or have different opportunities for learning than men.

\subsection{Financial decision-making within the household}

Several papers make a compelling case that differences in financial literacy emerge due to specialization within the household, where men traditionally make the majority of household financial decisions (Hsu, 2011, and Fonseca et al., 2010). Thus, women in a partnership (married or living with a partner) may accumulate less financial knowledge than men. Yet, because women tend to outlive men, there is an incentive for women to acquire financial knowledge when they become widowed. In Table 4 we present level of financial literacy by marital status. Because of the rich data in the three countries under consideration, we can also consider respondents' decision-making role within the household.

What we find is that married women exhibit lower levels of financial literacy than married men, a result that holds true across countries. However, gender differences are large even for respondents who have experienced a marital breakup (those who are divorced or widowed; but note that the number of observations in these subgroups is small). Moreover, widows show very low levels of financial literacy across all countries. There is a gender gap in financial literacy even between single men and single women. In the United States, in particular, single women display very low levels of financial literacy in comparison with single women in the Netherlands and Germany. The regression results presented in the previous section point in a similar direction; the financial literacy gender gap remains almost unchanged in all three countries when taking marital status into account (see column 2 in Table 2). In other words, this variable alone is not able to explain the size of the gender gap we see in the data.

\section{(Table 4 about here)}

Marital status may, however, be an imperfect proxy for identifying the decision maker in the household. In all our data sets we are able to identify who the decision maker in the household is. Moreover, we can analyze the relationship between gender and financial decision making roles. We identify four groups of decision makers: (i) "Sole decision maker with partner," i.e., decision makers who live with a partner but individually decide about financial issues; (ii) "sole decision maker without partner," i.e., singles and widows; (iii) respondents who claim that their "partner makes most financial decisions"; and (iv) "joint decision makers." "2 Our results indicate that female sole decision makers without a partner have lower levels of

\footnotetext{
${ }^{12}$ In the German case this can be jointly with a person outside the household.
} 
financial literacy than do male sole decision-makers without a partner (Table 5). Female respondents who decide jointly with their partner also know significantly less than respective male respondents. ${ }^{13}$ Thus, even when they are the decision maker, women display lower financial knowledge than male decision makers. Overall, we find it worrisome that women who have to decide by themselves, i.e., single women and widows, show such low levels of financial literacy.

(Table 5 about here)

\subsection{Gender differences in financial literacy between East and West Germany}

The German SAVE allows us to shed more light on gender differences and the channels though which financial literacy may be acquired by investigating gender differences in financial literacy between East and West Germany. Individuals in these two regions were exposed to different financial markets and institutions before German unification. Thus, we can study the size of the gender gap in financial knowledge in East and West Germany twenty years after unification and assess how well respondents living in the East perform on financial literacy questions compared to those living in the West. This comparison may provide insight into the roots of the gender differences we have documented so far.

Women (men) in the West are significantly more likely to answer all three financial literacy questions correctly compared to women (men) in the East (Bucher-Koenen and Lusardi, 2011). Thus, even twenty years after German unification, there is still a significant gap in financial knowledge between respondents from East and West Germany. Interestingly, there is a strong gender difference among respondents in the West but no significant gender difference among respondents living in East Germany. Thus, history and experience can be at the root of learning, a fact confirmed in other studies. Lusardi and Mitchell (2011b) find, for example, that American respondents who had been exposed to inflationary episodes are more likely to know about inflation, while Japanese respondents who had a long experience with deflation are much more likely to respond with "do not know" to the question about inflation.

One reason that has been put forward to explain the lack of gender differences in the East is that women's labor market participation is higher in East Germany than in West Germany. However, the gender disparity in the West remains significant even after controlling for income, education, and labor market status in a multivariate regression, whereas the gender difference in the East remains insignificant.

Previously we reported that there are no gender differences in financial literacy in Russia, another former Communist country where financial markets were not well developed. The lack of gender difference in financial literacy may be related to the fact that the former Communist societies were much more egalitarian with respect to gender roles. On the other hand, the findings in East Germany and Russia could also be interpreted as prima facie evidence that as financial markets develop, women are left behind in terms of financial knowledge. If this is the case, the financial market development of recent years may lead to the emergence of a gender gap in these former Communist societies. However, more research is necessary to understand how and under what circumstances men and women acquire financial knowledge.

\footnotetext{
${ }^{13}$ There are no significant gender disparities for individuals who are sole decision-makers and live with a partner or between men and women claiming that their partner makes the decisions. We must note, however, that these groups are small, so inferences are tentative.
} 


\section{Are women aware of their lack of knowledge?}

In addition to providing information about actual levels of financial literacy, the surveys in the United States, the Netherlands, and Germany offer information about self-assessed financial literacy. It is thus possible to evaluate not just how much people actually know but also how much they think they know. Moreover, differences in self-assessed literacy are important because subjective knowledge has an independent effect on financial decision-making (Hadar, Sood, and Fox, 2010). Most important for this paper, it is possible to evaluate whether there are gender differences not only in financial literacy but also in self-reported literacy and, moreover, whether the mismatch between actual and perceived knowledge is different for women and men.

In all three surveys, respondents were asked the following question:

"On a scale from 1 to 7, where 1 means very low and 7 means very high, how would you assess your overall financial knowledge?"

Figures $2 \mathrm{~A}-2 \mathrm{C}$ show the self-assessed literacy for men and women in the American, Dutch, and German samples, respectively.

(Figures 2A-2C about here)

While many American respondents fared rather poorly on the three financial literacy questions, results in Figure 2A indicate that a high proportion of American respondents gave themselves high self-assessment scores. Around two-fifths (38\%) of respondents awarded themselves top scores (6 and 7), and only $13 \%$ gave themselves very low scores $(1,2$, or 3$)$. Overall, about $70 \%$ of respondents indicated that their knowledge exceeds the median score (4), a figure that is surprising given the actual number of correct responses to the financial literacy questions. We have seen that women - based on the three knowledge questions - are less financially literate than men. Although American women do assign themselves slightly lower financial knowledge scores, the differences in self-assessed financial literacy between women and men are relatively small and not significant.

Dutch respondents are somewhat less conservative about their financial knowledge than American respondents (See Figure 2B). On average, about 27\% of the Dutch assessed themselves as knowledgeable about financial issues ( 6 or 7$)$, and $18 \%$ evaluated themselves as being at the bottom of the scale $(1,2$, or 3$)$. But even in the Netherlands, about $60 \%$ of respondents considered their knowledge to be above median (a score of 4). But, relevant to our analysis, female respondents gave themselves lower scores than men. Twenty-one percent assigned themselves a 6 or 7 , and $22 \%$ ranked themselves as having low financial literacy. Thus, many Dutch women seem to be aware of their lack of knowledge.

German respondents rate themselves even more conservatively than respondents from the Netherlands and the United States (See Figure 2C). Only a little more than 22\% assessed themselves as being very knowledgeable ( 6 or 7$)$; roughly the same percentage $(23 \%)$ rated themselves as not knowledgeable $(1,2$, or 3$)$. Overall, only slightly more than half of the respondents (54\%) evaluated themselves as having an above-median score (4). Similar to the Netherlands, German women rated themselves more conservatively than men. Twenty-one percent of women evaluated themselves as having high financial literacy, and $24 \%$ assigned themselves to the lower literacy ranks. 
In Figures 3A-3C we compare actual and subjective financial literacy between men and women. We evaluate the percentage of individuals among each self-rated category who were able to correctly answer the three financial literacy questions and the percentage of those with at least one "do not know" response. We find a rather strong correlation between actual and self-assessed financial knowledge for both men and women in all three countries. The percentage of respondents who answered all questions correctly increases as self-assessed knowledge increases; the share of those with at least one "do not know" answer declines as self-assessed knowledge declines. Interestingly, the percentage of women who correctly answered all three questions and gave themselves high scores (6 or 7) is not very high, while a relatively high proportion of women who answered with at least one "do not know" gave themselves high scores. This may indicate that "do not know" responses reflect not simply lack of knowledge but difficulty in articulating the answer to a specific question and/or lack of confidence in the answer.

(Figures 3A-3C about here)

Overall we have a consistent set of findings on gender differences in financial literacy in the three countries. Female respondents are less likely to respond correctly and more likely to state that they do not know the answer to a financial literacy question. Additionally, when asked to assess their financial knowledge, women assign themselves lower scores than men.

\section{Seeking financial advice}

Having established that a gender gap exists in financial literacy, and in more than one country, the important question is whether this gap matters for financial decision making. One way to overcome lack of financial knowledge is to ask for financial advice. If women recognize their lack of knowledge, as discussed in the previous section, one way to potentially compensate for lack of knowledge would be to rely on professional financial advisors when making financial decisions. However, several studies show that women are much less likely ask for advice (see Loibl and Hira, 2006) and are less likely to use online resources as a source of information (Loibl and Hira, 2011).

We present evidence on sources of financial advice among Dutch and German respondents in Table $6 .{ }^{14}$ First, we note that only a small proportion of the population rely on professional advice. Professional financial advisors are the main source of financial information for about $25 \%$ of Dutch respondents. More than half of respondents get their information mainly from the Internet, newspapers, magazines, and other written sources, and about $23 \%$ consult family and friends. However, women are much more likely than men to report family and friends as their main source of information (30\% vs. 19\%). Men and women are almost equally likely to rely on a financial professional. If we look at sources of financial information across levels of financial literacy among Dutch respondents, we find that those with high financial literacy, i.e., those able to correctly answer the three financial literacy questions, are more likely to consult professional financial advisors $(26 \%)$ than are respondents with low financial literacy $(21 \%)$. Those with low levels of literacy are much more likely to rely on family and friends as their main source of financial information (32\% vs. 20\%). This finding supports work that shows that financial literacy and financial advice are complements rather than substitutes (Hackethal et al. 2012; Collins, 2012; Bucher-Koenen and Koenen, 2014).

\footnotetext{
${ }^{14}$ Questions on professional advice are asked differently in the United States and are not directly comparable.
} 
Of German respondents, about one-third state that they do not consult anyone when making financial decisions, another third consult professional advisors, and around $50 \%$ talk to family, friends, or colleagues about their finances (Table 6; Panel B). ${ }^{15}$ Looking at sources of financial advice by gender, we find that women are much more likely than men to consult informal sources of advice ( $53 \%$ vs. $44 \%$ ), while men are slightly more likely to consult professional advisors ( $31 \%$ vs. $35 \%)$. If we split the sample by financial literacy level instead of gender, the difference becomes more pronounced. About $43 \%$ of respondents with low levels of financial literacy do not talk to anyone about their finances. This fraction is much lower among those with high levels of financial literacy (26\%). In turn, those with high levels of financial literacy are much more likely to consult professional advisors (40\%), whereas only $23 \%$ of those with low literacy rely on the services of professionals.

One of the reasons why women, who have lower financial literacy than men, are less likely to consult professional advisors is because they may have difficulty judging the quality of the advice they receive. Women may be unable to find a good financial advisor or may not know what to do when they have a conflict with an advisor (Alcon, 1999). In an audit study of financial advice, Mullainathan, Nöth, and Schoar (2012) found that young female investors received lower quality advice than young male investors. Advisors were less likely to ask women for personal information that would tailor the advice to their needs, and women were less frequently advised to invest in stocks or bonds. Most importantly, advisors were much more inclined to ask women to transfer their funds before providing them with advice, meaning that female investors were pressured to choose an advisor before knowing anything about the quality of the advice that they would receive. This is in line with the theoretical and empirical work by Bucher-Koenen and Koenen (2014), who set up a model of financial advice and financial literacy in which advisors have an incentive to offer clients with low financial literacy lower quality advice. This tailoring of advice is confirmed empirically.

Overall, there is little evidence that women with low financial literacy are more likely to consult professionals when making financial decisions in order to compensate for their lack of knowledge. On the contrary, women and those with low financial literacy are less likely to turn to financial advisors. This strategy may be rational because women seem to be more likely to receive low-quality advice. Unfortunately, if low financial literacy and lack of financial advice feed into each other, women may not acquire the skills or receive the support necessary to make sound financial decisions.

\section{Does the gender gap in financial literacy matter?}

Having established that there are large differences in financial literacy between men and women, we now turn to the question of whether this has an effect on the quality of personal financial decisions and financial well-being. We discuss two separate strands of literature: one that investigates the link between financial literacy and financial decision-making, and another that examines gender and financial well-being.

An increasing number of studies investigate the effect of financial literacy on financial decision-making. Individuals with low financial knowledge are found to be less likely to plan for retirement, a finding that holds true in the United States, Germany, and the Netherlands

\footnotetext{
${ }^{15}$ Note that the findings from Germany may not be strictly comparable to those from the Dutch DHS because the question was asked in a rather different way. Results do not add up to $100 \%$ because respondents can consult both formal and informal sources of advice at the same time.
} 
(Lusardi and Mitchell, 2007, 2009, 2011a,c; Bucher-Koenen and Lusardi, 2011; Van Rooij, Lusardi, and Alessie, 2011b, 2012). These findings also hold true when looking at a sample of older women in the United States (Lusardi and Mitchell, 2008). Moreover, individuals with low financial literacy are less likely to invest in risky but potentially high-yielding assets such as stocks or bonds (Van Rooij, Lusardi, and Alessie, 2011a; Yoong, 2011) and are more likely to make financial mistakes such as borrowing at high rates (Lusardi and Tufano, 2009a; Agarwal et al., 2009), making financial losses permanent (Bucher-Koenen and Ziegelmeyer 2013) or failing to minimize fees (Hastings, Mitchell, and Chyn, 2011). Mottola (2013) found that women with low levels of financial literacy were more likely to engage in costly credit card behavior than men. Those with more financial knowledge hold much higher levels of wealth (Van Rooij, Lusardi, and Alessie, 2012). Thus, if women, on average, have lower levels of financial literacy and do not obtain high-quality financial advice, they may be at risk of failing to plan for retirement and making other financial mistakes. Alcon (1999) finds that women perceive their lack of financial knowledge as an obstacle to financial planning.

The second strand of literature deals with gender and financial well-being. Jefferson (2009) provides a review of the literature on gender and pensions. Because in most countries pension benefits are related to contributions made during one's working life, gender gaps in income and labor force participation can translate into lower pension income for women. With pension reforms shifting responsibility from state pensions to occupational and private pensions, the link between labor market status and retirement income will become even stronger, potentially widening the gender gap in retirement income. On the other hand, the shift from defined benefit (DB) to defined contribution (DC) pension plans enhances freedom of choice and increases opportunities to manage risk related to human capital and social security wealth (see Baxter, 2002). However, this requires women to be aware of the risks associated with the different forms of capital and to efficiently manage those risks.

Currently, the data show a prevalence of poverty among older women. Siegenthaler (1996) provides an overview of studies examining old-age poverty. He reports that poverty rates among single female households in the United States and Germany are high compared to other countries. Sevak, Weir, and Willis (2003/2004) as well as Weir and Willis (2000) report evidence that elderly women in the United States have a high likelihood of becoming poor. The threat of old-age poverty is particularly high for women with low socioeconomic status prior to widowhood, because they tend to become widowed earlier due to the correlation between socioeconomic status and mortality. The authors consider this worrisome because elderly widows have few alternatives for enhancing their financial situation. They argue that this is related to insufficient insurance and financial preparation, especially among women who become widowed between age 50 and 65 (see also Weir and Willis, 2003). Biro (2011) examined the economic and health situation of elderly people in Europe and found that female widows above the age of 50 are ten percentage points more likely to report financial difficulties compared to single and married women of the same age. No such differences are found for men.

There are also a large number of studies that point to the difficulties that women face with other decisions. For example, women are more inclined to reply "do not know" to survey questions about their expected retirement age and expected retirement income (Alessie, Van Rooij, and Lusardi, 2011b). Hurd and McGarry (1995) as well as Teppa (2011) report evidence that women tend to underestimate their own life expectancy. Therefore they may insufficiently prepare for retirement. 
Women are also less likely to have defined contribution pension plans (Sundén and Surette, 1998), and they invest more conservatively, i.e., they are less likely to own stocks and more likely to invest in fixed-income securities (see Almenberg and Dreber, 2011; Bajtelsmit and VanDerhei, 1997; Hinz, McCarthy, and Turner, 1997; and Sundén and Surette, 1998). Additionally, there are gender differences not only with respect to long-term saving and investment behavior, but also with respect to short-term objectives and behavior. Hira and Mugenda (2000), for instance, find that women are more likely to shop compulsively or without need and are less satisfied with their ability to handle financial emergencies. Alesina, Lotti, and Mistrulli (2013) examine credit conditions of self-employed and small business owners in Italy and show that female borrowers systematically get worse credit conditions, even after controlling for risk characteristics and bank fixed effects.

All in all, the existing evidence points to the fact that women and those with low financial literacy have difficulties making financial decisions and that this can have severe consequences for their financial well-being.

\section{Concluding remarks}

The analysis of financial literacy in different countries and in different population subgroups has shown that financial illiteracy is particularly severe among women. This has far-reaching consequences, because financial literacy can be linked to important financial decisions, such as planning for retirement and accumulating retirement wealth.

Particularly worrisome is that financial illiteracy is more widespread among single women and widows, who do not have a partner or spouse to consult when making financial decisions. Moreover, the gender gap in financial literacy is still present among the young. A low level of financial knowledge may have serious consequences because of the increasing individual responsibility for retirement security. The shift from DB to DC systems may have major consequences for women because of their lower levels of financial knowledge in addition to lower incomes during their working lives, interrupted employment histories, and longer life expectancies. Moreover, women are very likely to spend at least part of their retirement as widows. The evidence suggests that it is particularly difficult for women to obtain independent, high-quality advice. Therefore, enhancing the financial knowledge of women and equipping them with the tools to make sound financial decisions should be a top priority for policymakers.

While more research is needed to understand the sources of gender differences in financial literacy, the good news is that many women recognize their lack of knowledge, as indicated by their tendency to rate themselves low on a personal financial knowledge scale. This awareness makes them an ideal target for financial education programs. Previous research has shown that financial education programs seem to be particularly successful for women. For example, Clark et al. (2006) provide evidence that women are more likely than men to change their behavior after attending a seminar on retirement goals and saving behavior. Specifically, they are more likely to increase their retirement age and adjust their saving behavior. Lusardi, Keller, and Keller (2008) show that financial education programs can be rather effective for women. Focus groups and in-depth interviews with women reveal that women would like such programs to be offered. In view of the gender differences found in the research, an effective way forward for financial education programs is to target women and men separately and to offer programs that recognize the differences between women and men in terms of both financial knowledge and financial behavior. 


\section{References}

Agarwal, Sumit, John C. Driscoll, Xavier Gabaix, and David Laibson (2009), "The age of reason: Financial decisions over the life cycle and implications for regulation," Brookings Papers on Economic Activity, Fall 2009, pp. 51-117.

Agnew, Julie R., and Lisa R. Szykman (2005), "Asset allocation and information overload: The influence of information display, asset choice and investor experience," The Journal of Behavioral Finance, 6(2), pp. 57-70.

Agnew, Julie R., Lisa R. Anderson, Jeffrey R. Gerlach, and Lisa R. Szykman, (2008), "Who Chooses Annuities? An Experimental Investigation of the Role of Gender, Framing, and Defaults," American Economic Review, 98(2), pp. 418-422.

Agnew, Julie R., Hazel Bateman, and Susan Thorp (2013), "Financial Literacy and Retirement Planning in Australia," Numeracy, 6(2), 7.

Alcon, Arnaa (1999), "Financial planning and the mature woman," Journal of Financial Planning, 12(2), pp. 82-88.

Alesina, Alberto F., Francesca Lotti, and Paolo Emilio Mistrulli (2013), "Do Women Pay More for Credit? Evidence from Ital," Journal of the European Economic Association 11(s1), pp. 45-66.

Alessie, Rob, Maarten van Rooij, and Annamaria Lusardi (2011a), "Financial literacy and retirement preparation in the Netherlands," Journal of Pension Economics and Finance, 10(4), pp. 527-545.

Alessie, Rob, Maarten van Rooij, and Annamaria Lusardi (2011b), "Financial literacy, retirement preparation and pension expectations in the Netherlands," DNB Working Paper no. 289.

Almenberg, Johan, and Anna Dreber (2011), "Gender, Financial Literacy and Stock Market Participation," Stockholm School of Economics Economic Research Institute Working Paper, 737.

Almenberg, Johan, and Jenny Säve-Söderbergh (2011), "Financial literacy and retirement planning in Sweden," Journal of Pension Economics and Finance, 10(4), pp. 585-598.

Arrondel, Luc, Majdi Debbich, and Frédérique Savignac (2013), "Financial Literacy and Financial Planning in France," Numeracy, 6(2), 8.

Bajtelsmit, Vickie L., and Jack L. VanDerhei (1997), "Risk aversion and pension investment Choices," in Positioning pensions for the twenty-first century, edited by Michael S. Gordon, Olivia S. Mitchell, and Marc M. Twinney. Philadelphia: University of Pennsylvania Press, pp. 45-66.

Baxter, Marianne (2002), "Social Security as financial asset: Gender-specific risks and returns", Journal of Pension Economics and Finance, 1(1), pp. 35-52. 
Beckmann, Elisabeth (2013), "Financial Literacy and Household Savings in Romania," Numeracy, 6(2), 9.

Biro, Aniko (2011), "Poverty of widows in Europe", discussion paper, Central European University, The University of Edinburgh.

Boisclair, David, Annamaria Lusardi and Pierre-Carl Michaud (2014), "Financial Literacy and Retirement Planning in Canada," NBER Working Paper n. 20297.

Börsch-Supan, Axel, Michela Coppola, Lothar Essig, Angelika Eymann, and Daniel Schunk (2009), "The German SAVE Study - Design and Results," $2^{\text {nd }}$ ed., Mannheim Institute for the Economics of Aging (MEA).

Bucher-Koenen, Tabea, and Johannes Koenen (2014), "Do smarter consumers get better advice?," working paper, Max-Planck-Institute for Social Law and Social Policy.

Bucher-Koenen, Tabea (2011), "Financial literacy, Riester pensions and other private old age provision in Germany," Max-Planck-Institute for Social Law and Social Policy, MEA Discussion Paper 250-11.

Bucher-Koenen, Tabea, and Annamaria Lusardi (2011), "Financial literacy and retirement planning in Germany," Journal of Pension Economics and Finance, 10(4), pp. 565-584.

Bucher-Koenen, Tabea, and Michael Ziegelmeyer (2013), "Once Burned, Twice Shy? Financial Literacy and Wealth Losses during the Financial Crisis," Review of Finance, forthcoming.

Brown, Martin, and Roman Graf (2013), "Financial Literacy and Retirement Planning in Switzerland," Numeracy, 6(2), 6.

Chen, Haiyang, and Ronald P. Volpe (1998), "An analysis of personal financial literacy among college students," Financial Services Review, 7(2), pp. 107-128.

Chen, Haiyang, and Ronald P. Volpe (2002), "Gender differences in personal financial literacy among college students," Financial Services Review, 11(3), pp. 289-307.

Clark, Robert L., Madeleine D’Ambrosio, Ann A. McDermed, and Kshama Sawant (2006), "Retirement plans and saving decisions: The role of information and education," Journal of Pension Economics and Finance, 5(1), pp. 45-67.

Crossan, Diana, David Feslier, and Roger Hurnard (2011), "Financial literacy and retirement planning in New Zealand," Journal of Pension Economics and Finance, 10(4), pp. 619-635.

Collins, M. (2012), "Financial advice: A substitute for financial literacy?," Financial Services Review, 21(4), pp. 307-322

Fonseca, Raquel, Kathleen J. Mullen, Gema Zamarro, and Julie Zissimopoulos (2010), "What explains the gender gap in financial literacy? The role of household decision making," Journal of Consumer Affairs, 46(1), pp. 90-106. 
Ford, Matthew W., and Daniel W. Kent (2010), "Gender differences in student financial market attitudes and awareness: An exploratory study," Journal of Education for Business, $85(1)$, pp. 7-12.

Fornero, Elsa, and Chiara Monticone (2011), "Financial literacy and pension plan participation in Italy," Journal of Pension Economics and Finance, 10(4), pp. 547-564.

Goldsmith, Elizabeth, and Ronald E. Goldsmith (1997), "Gender differences in perceived and real knowledge of financial investments," Psychological Reports, 80(1), pp. 236-238.

Hackethal, A., Haliassos, M., \& Jappelli, T. (2012), "Financial advisors: A case of babysitters?," Journal of Banking \& Finance, 36(2), pp. 509-524.

Hadar, Liat, Sanjay Sood, and Craig Fox (2010), "It's not only what you know but also how knowledgeable you feel: Subjective knowledge in consumer financial decisions," Unpublished manuscript, University of California, Los Angeles.

Hastings, Justine, Olivia S. Mitchell, and Eric Chyn (2011), "Fees, framing, and financial literacy in the choice of pension manager," Financial literacy: Implications for retirement security and the financial marketplace, pp. 101-115.

Hinz, Richard P., David D. McCarthy, and John A. Turner (1997), "Are women conservative investors? Gender differences in participant directed pension investments," in Positioning pensions for the twenty-first century, edited by Michael S. Gordon, Olivia S. Mitchell, and Marc M. Twinney. Philadelphia: University of Pennsylvania Press, pp. 91-103.

Hira, Tahira K., and Olive Mugenda (2000), "Gender differences in financial perceptions, behavior and satisfaction," Journal of Financial Planning, 13(2), pp. 86-92.

Hogarth, Jeanne, and Marianne Hilgert (2002), "Financial knowledge, experience and learning preferences: Preliminary results from a new survey on financial literacy," Consumer Interest Annual, 48(1), pp. 1-7.

Hilgert, Marianne, Jeanne Hogarth, and Sondra Beverly (2003), "Household financial management: The connection between knowledge and behavior," Federal Reserve Bulletin, 89, pp. 309-322.

Hsu, Joanne W. (2011), “Aging and strategic learning: The impact of spousal incentives on financial literacy," Networks Financial Institute Working Paper, no. 2011-WP-06, Indiana State University.

Hung, Angela A, Andrew M. Parker, and Joanne K. Yoong (2009), "Defining and measuring financial literacy," RAND Working Paper, no. WR-708.

Hurd, Michael D., and Kathleen McGarry (1995), "Evaluation of the subjective probabilities of survival in the health and retirement study," Journal of Human Resources, pp. S268-S292.

Jefferson, Therese (2009), "Women and retirement pensions: a research review," Feminist Economics, 15(4), pp. 115-145. 
Klapper, Leora, and Georgios A. Panos (2011), "Financial literacy and retirement planning: The Russian case,” Journal of Pension Economics and Finance, 10(4), pp. 599-618.

Loibl, Cäzilia, and Tahira K. Hira (2006), “A workplace and gender-related perspective on financial planning information sources and knowledge outcomes," Financial Services Review, 15(1), pp. 21-42.

Loibl, Cäzilia, and Tahira K. Hira (2011), "Know your subject: A gendered perspective on investor information search," Journal of Behavioral Finance, 12(3), pp.117-130.

Lusardi, Annamaria, Punam Keller, and Adam Keller (2008), "New ways to make people save: a social marketing approach," in Overcoming the Saving Slump: How to Increase the Effectiveness of Financial Education and Saving Programs, edited by Annamaria Lusardi, Chicago: University of Chicago Press, pp. 209-236.

Lusardi, Annamaria, and Olivia S. Mitchell (2007), "Baby boomers retirement security: the role of planning, financial literacy and housing wealth," Journal of Monetary Economics, 54(1), pp. 205-224.

Lusardi, Annamaria, and Olivia S. Mitchell (2008), "Planning and financial literacy: How do women fare?," American Economic Review, 98(2), pp. 413-417.

Lusardi, Annamaria, and Olivia S. Mitchell (2009), "How ordinary consumers make complex economic decisions: Financial literacy and retirement readiness," NBER Working Paper no. 15350 .

Lusardi, Annamaria, and Olivia S. Mitchell (2011a), "Financial literacy and planning: Implications for retirement wellbeing," in Olivia S. Mitchell and Annamaria Lusardi (eds.), Financial Literacy: Implications for Retirement Security and the Financial Marketplace. Oxford: Oxford University Press, pp. 17-39.

Lusardi, Annamaria, and Olivia S. Mitchell (2011b), "Financial literacy around the world: An overview," Journal of Pension Economics and Finance, 10(4), pp. 497-508.

Lusardi, Annamaria, and Olivia S. Mitchell (2011c), "Financial literacy and retirement planning in the United States," Journal of Pension Economics and Finance, 10(4), pp. 509525.

Lusardi, Annamaria, and Olivia S. Mitchell (2014), "The economic importance of financial literacy: Theory and evidence," Journal of Economic Literature, 52(1), pp. 5-44.

Lusardi, Annamaria, Olivia S. Mitchell, and Vilsa Curto (2010), "Financial literacy among the young," Journal of Consumer Affairs, 44(2), pp. 358-380.

Lusardi, Annamaria, Olivia S. Mitchell, and Vilsa Curto (2014), "Financial sophistication in the older population," Journal of Pension Economics and Finance, 1 3(4), pp. 347-366.

Lusardi, Annamaria, and Peter Tufano (2009a), "Debt literacy, financial experiences, and overindebtedness," NBER Working Paper, no. 14808. 
Lusardi, Annamaria, and Peter Tufano (2009b), "Teach workers about the peril of debt," Harvard Business Review, November, pp. 22-24.

Mahdavi, Mahnaz and Nicholas Horton (2012), "Financial literacy among educated women: Room for improvement,"Journal of Consumer Affairs, 48, pp. 403-417.

Mandell, Lewis (2004), "Financial literacy: Are we improving? Results of the 2004 National Jump\$tart Survey," Washington, D.C.: Jump\$tart Coalition for Personal Financial Literacy.

Mandell, Lewis (2008), "Financial education in high school," in Annamaria Lusardi (ed.), Overcoming the Saving Slump: How to Increase the Effectiveness of Financial Education and Saving Programs, Chicago: University of Chicago Press, pp. 257-279.

Moore, Donna (2003), "Survey of financial literacy in Washington State: Knowledge, behavior, attitudes and experiences," Technical Report 03-39, Social and Economic Sciences Research Center, Washington State University.

Mottola, Gary (2013), "In our best interest: Women, financial literacy and credit card behavior", Numeracy, 6(2), 4.

Mullainathan, Sendhil, Markus Nöth, and Antoinette Schoar (2012), "The market for financial advice: An audit study,” NBER Working Paper, no. 17929.

Sekita, Shizuka (2011), "Financial literacy and retirement planning in Japan," Journal of Pension Economics and Finance, 10(4), pp. 637-656.

Sevak, Purvi, David R. Weir, and Robert J. Willis (2003/2004), "The economic consequences of husband's death: Evidence from HRS and AHEAD," Social Security Bulletin, 65(3), pp.3144.

Siegenthaler, Jurg K. (1996), "Poverty among single elderly women under different systems of old-age security: A comparative review," Social Security Bulletin, 59(3), pp. 31-44.

Sundén, Annija E., and Brian J. Surette (1998), "Gender differences in the allocation of assets in retirement savings plans," American Economic Review, 88(2), pp. 207-211.

Teppa, Federica (2011), "Can the longevity risk alleviate the annuitization puzzle? Empirical evidence from Dutch data,” DNB Working Paper No. 223.

Van Rooij, Maarten, Annamaria Lusardi, and Rob Alessie (2011a), "Financial literacy and stock market participation,” Journal of Financial Economics, 101(2), pp. 449-472.

Van Rooij, Maarten, Annamaria Lusardi, and Rob Alessie (2011b), "Financial literacy and retirement planning in the Netherlands," Journal of Economic Psychology, 32(4), pp. 593608.

Van Rooij, Maarten, Annamaria Lusardi, and Rob Alessie (2012), "Financial literacy, retirement planning, and households wealth," Economic Journal, 122(560), pp. 449-478. 
Weir, David, and Robert Willis (2000), "Prospects for widow poverty," in Forecasting Retirement Needs and Retirement Wealth, edited by Olivia S. Mitchell, P. Brett Hammond, and Anna M. Rappaport. Philadelphia: University of Pennsylvania Press, pp. 208-234.

Weir, David R., and Robert J. Willis (2003), "Widowhood, divorce, and loss of health insurance among near elderly women: evidence from the Health and Retirement Study," Michigan Retirement Research Center, Working Paper 2003-040.

Yoong, Joanne (2011), "Financial illiteracy and stock market participation: Evidence from the RAND American Life Panel," in Financial Literacy: Implications for Retirement Security and the Financial Marketplace, edited by Olivia S. Mitchell and Annamaria Lusardi. Oxford: Oxford University Press, pp. 76-97. 


\section{Figures}

Figure 1: Self-reported Financial Literacy for Men and Women in the US Financial Capability Study (Panel A), in the Dutch DHS (Panel B), and in the German SAVE (Panel C).

(A)
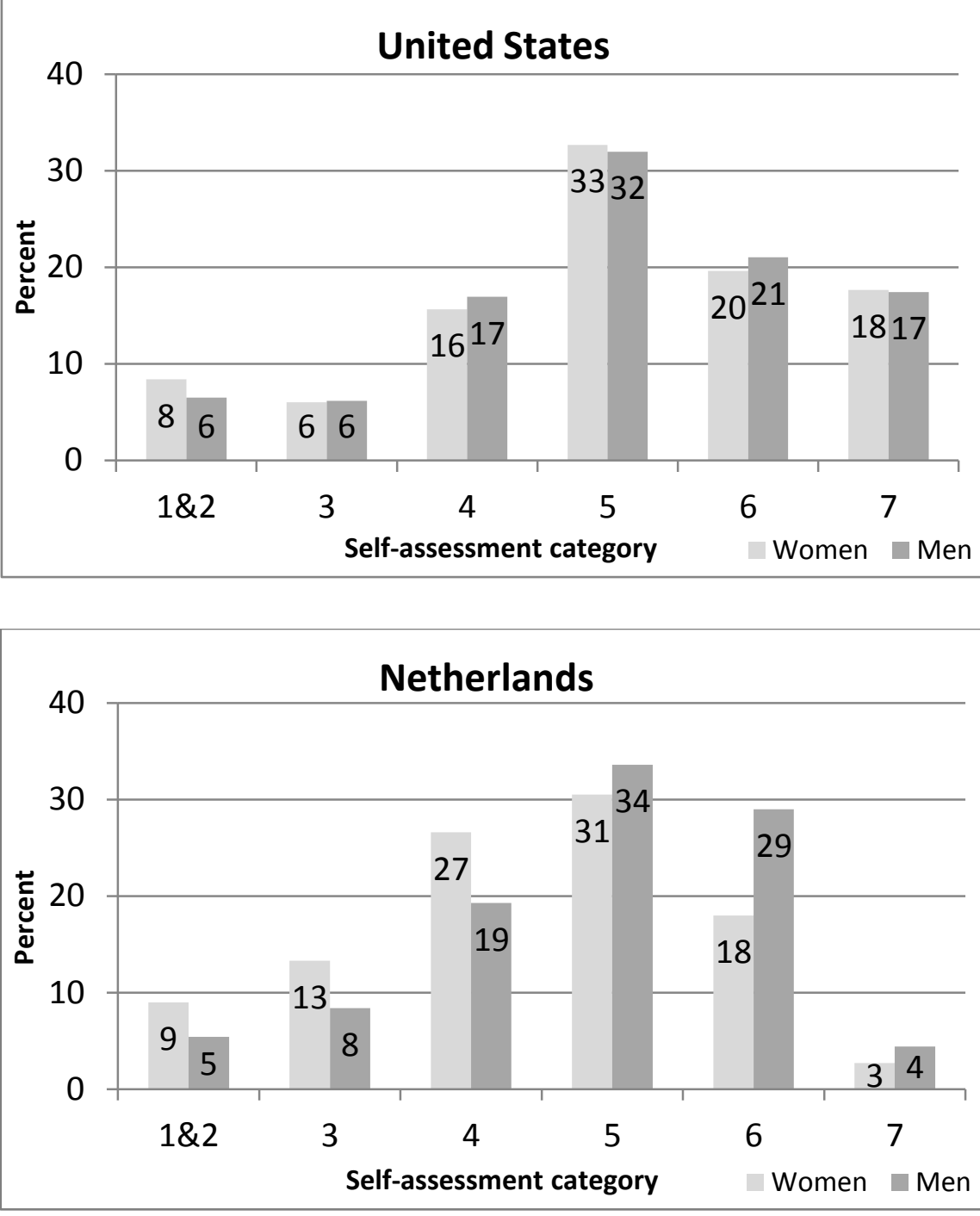

(B)

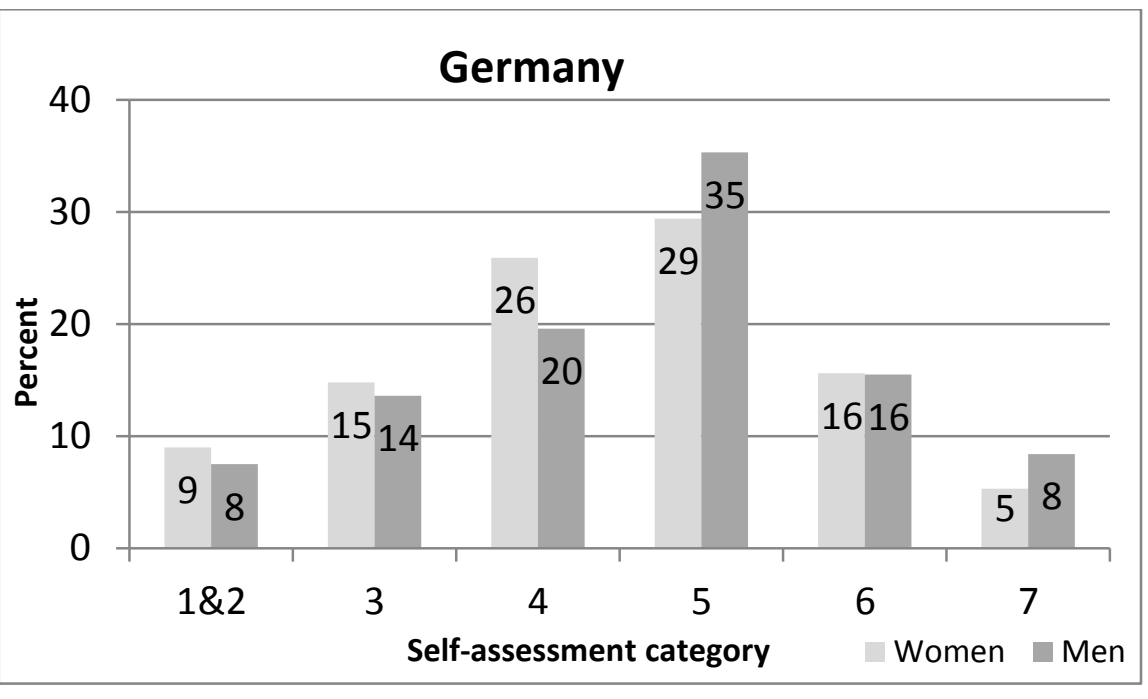


Figure 2: Self-reported and Actual Financial Literacy for Men and Women in the US Financial Capability Study (Panel A), in the Dutch DHS (Panel B), and in the German SAVE (Panel C).
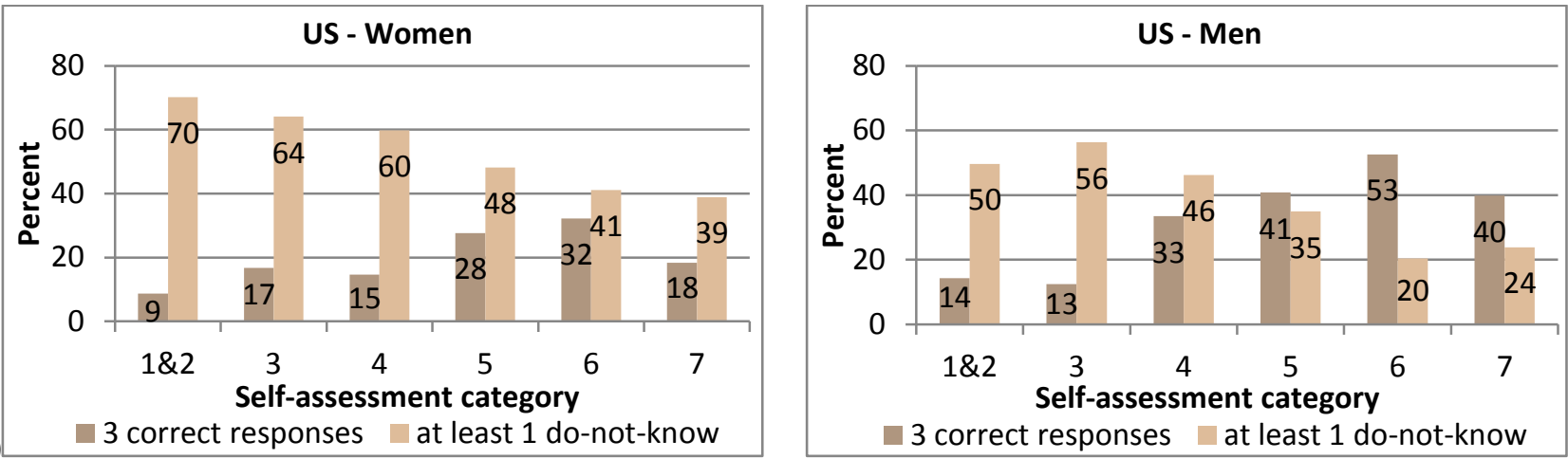

(A)
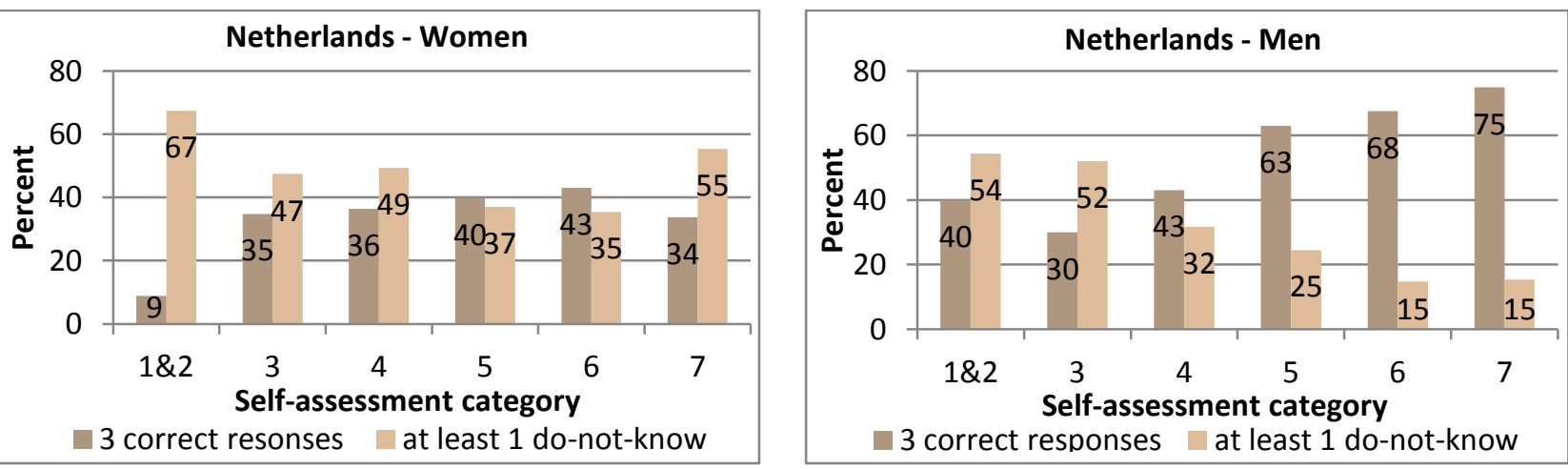

(B)
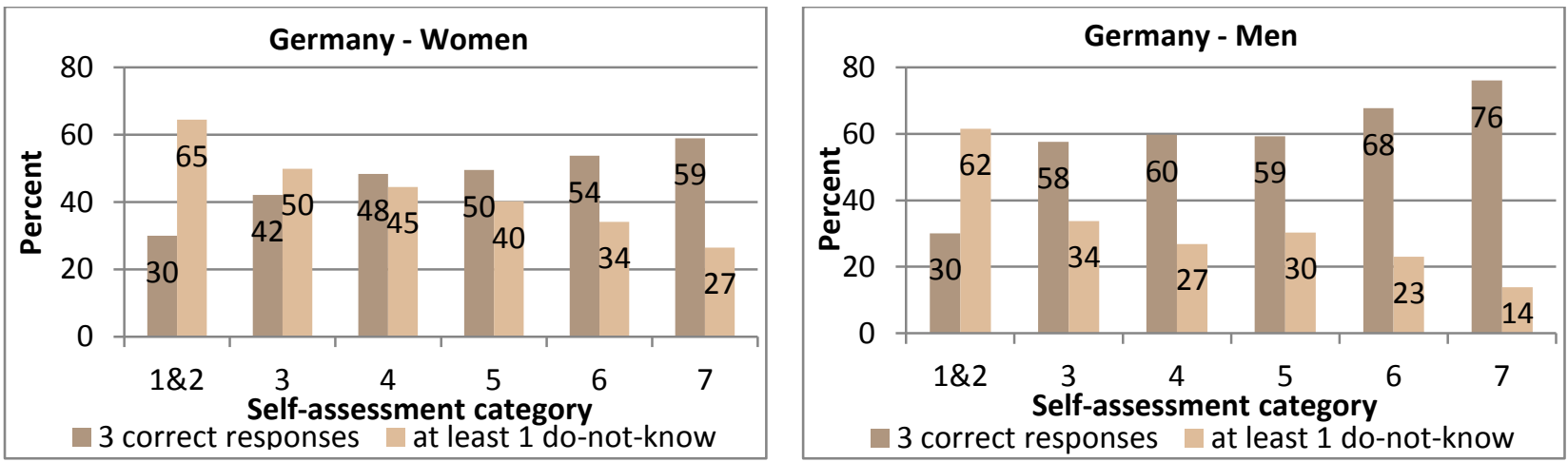
Figure 3: Financial Literacy by Age

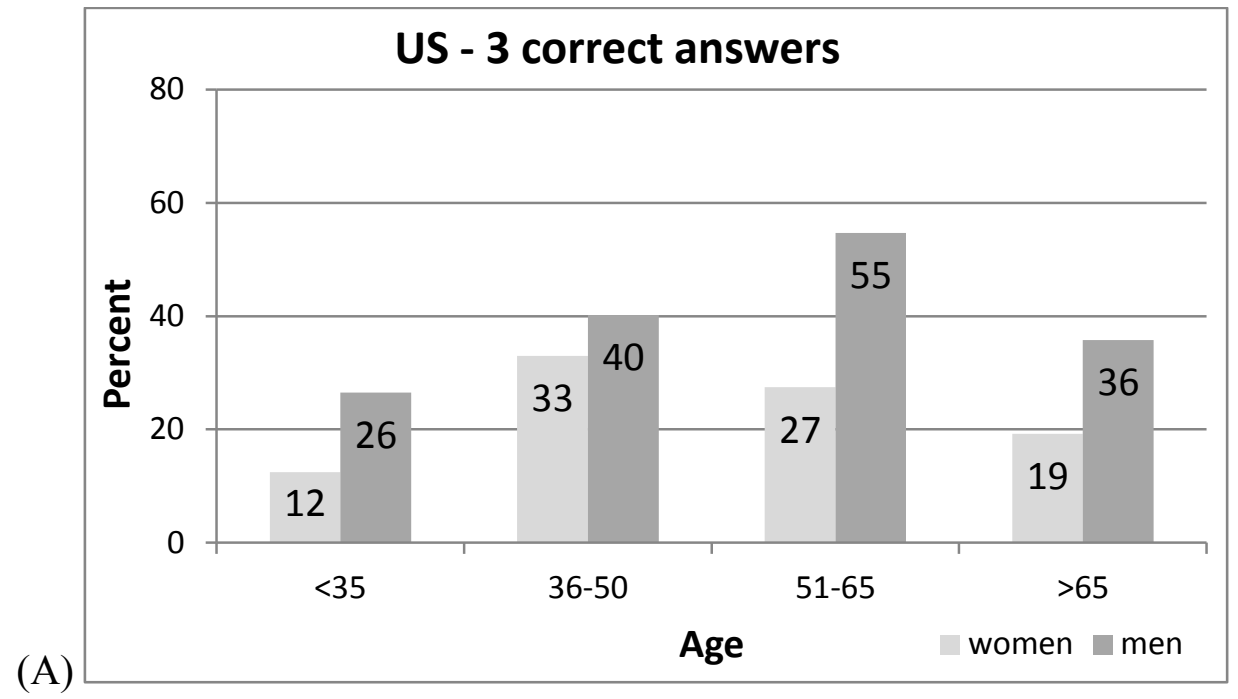

(A)

NL - 3 correct answers

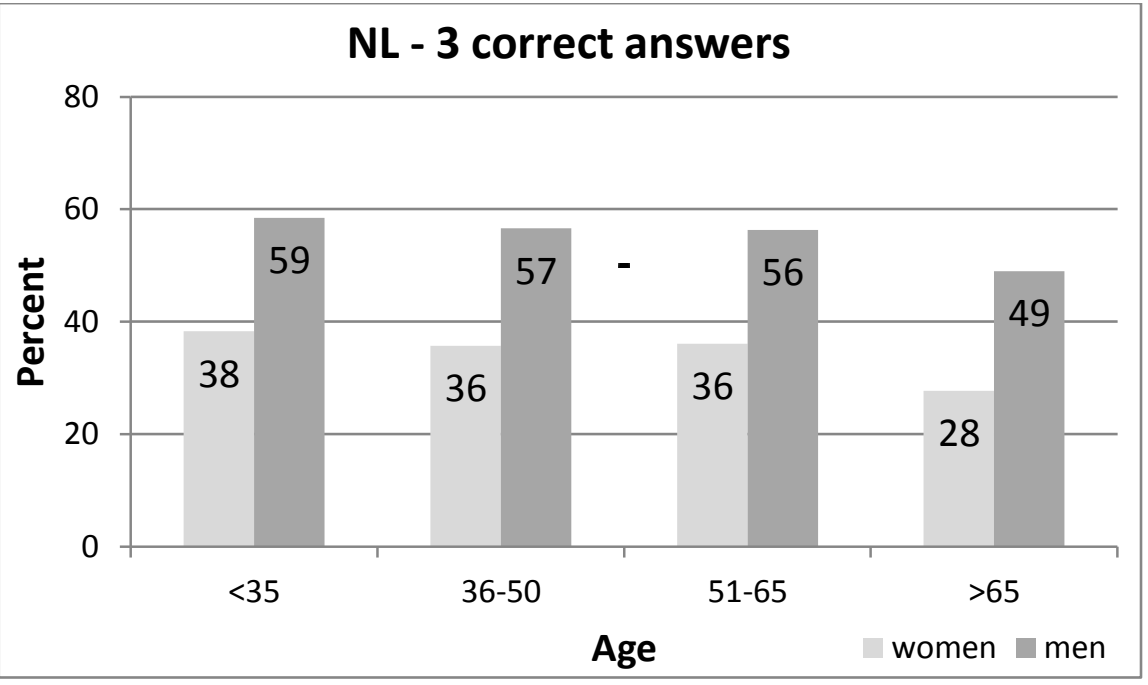

(B)

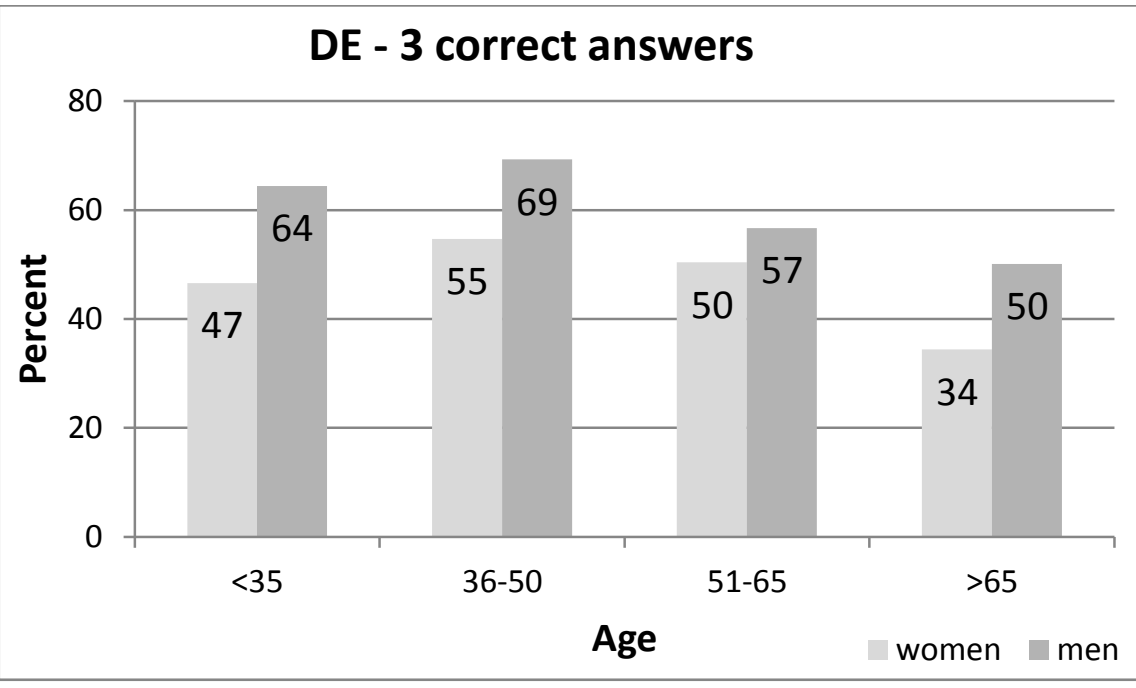

(C) 
Table 1a: Summary Statistics from the US 2009 Financial Capability Study (\%)

\begin{tabular}{llll}
\hline A: Interest Question & Full Sample & Female & Male \\
\hline$>\$ 102$ & 64.9 & 58.8 & 71.3 \\
$=\$ 102$ & 11.3 & 13.1 & 9.5 \\
$<\$ 102$ & 9.2 & 10.0 & 8.4 \\
Do not know & 13.5 & 16.6 & 10.3 \\
Refuse to answer & 1.0 & 1.5 & 0.5 \\
\hline B: Inflation Question & & & \\
\hline More & 11.2 & 12.3 & 10.0 \\
Exactly the same & 9.0 & 9.8 & 8.1 \\
Less & 64.3 & 58.0 & 71.0 \\
Do not know & 14.2 & 18.4 & 9.8 \\
Refuse to answer & 1.4 & 1.6 & 1.1 \\
\hline C: Risk Question & & & \\
\hline Correct (false) & 13.3 & 10.6 & 16.2 \\
Incorrect (true) & 51.8 & 46.8 & 57.1 \\
Do not know & 33.7 & 41.4 & 25.6 \\
Refuse to answer & 1.2 & 1.2 & 1.2 \\
\hline D: Cross-question Consistency & & & \\
\hline Interest \& Inflation & 46.2 & 37.7 & 55.2 \\
All correct & 30.2 & 22.5 & 38.3 \\
None correct & 12.3 & 15.1 & 9.3 \\
At least 1 do-not-know & 42.4 & 50.0 & 34.3 \\
All do-not-know & 4.7 & 6.3 & 3.0 \\
\hline \# Observations & 1488 & 768 & 720 \\
\hline \hline
\end{tabular}

Note: Distribution of responses to financial literacy questions in the full sample and for female and male respondents. All figures are weighted. 
Table 1b: Summary Statistics from the 2010 Dutch DNB Household Survey (\%)

\begin{tabular}{llll}
\hline A: Interest Question & Full Sample & Female & Male \\
\hline$>€ 102$ & 84.8 & 83.1 & 86.6 \\
$=€ 102$ & 3.4 & 4.3 & 2.5 \\
$<€ 102$ & 1.7 & 1.9 & 1.6 \\
Do not know & 8.9 & 9.5 & 8.3 \\
Refuse to answer & 1.1 & 1.1 & 1.1 \\
\hline B: Inflation Question & & & \\
\hline More & 2.7 & 2.8 & 2.7 \\
Exactly the same & 5.7 & 6.9 & 4.3 \\
Less & 76.9 & 72.0 & 81.9 \\
Do not know & 13.5 & 16.9 & 10.1 \\
Refuse to answer & 1.2 & 1.4 & 1.0 \\
\hline C: Risk Question & & & 62.0 \\
\hline Correct (false) & 51.9 & 42.1 & 10.5 \\
Incorrect (true) & 13.3 & 16.1 & 26.2 \\
Do not know & 33.2 & 39.9 & 1.3 \\
Refuse to answer & 1.6 & 1.9 & \\
\hline D: Cross-question Consistency & & & 78.6 \\
\hline Interest \& Inflation & 73.4 & 68.3 & 55.1 \\
All correct & 44.8 & 35.0 & 9.4 \\
None correct & 10.5 & 11.5 & 29.0 \\
At least 1 do-not-know & 37.6 & 45.9 & 8.0 \\
All do-not-know & 8.1 & 8.2 & 818 \\
\hline \# Observations & 1665 & 847 & \\
\hline \hline
\end{tabular}

Note: Distribution of responses to financial literacy questions in full sample and for female and male respondents. All figures are weighted. 
Table 1c: Summary Statistics from the 2009 German SAVE (\%)

\begin{tabular}{llll}
\hline A: Interest Question & Full Sample & Female & Male \\
\hline$>€ 102$ & 82.4 & 81.1 & 83.8 \\
$=€ 102$ & 3.0 & 3.2 & 2.8 \\
$<€ 102$ & 3.7 & 3.4 & 4.0 \\
Do not know/ refuse to answer & 11.0 & 12.4 & 9.4
\end{tabular}

\section{B: Inflation Question}

\begin{tabular}{llll}
\hline More & 0.9 & 0.5 & 1.3 \\
Exactly the same & 3.8 & 4.3 & 3.1 \\
Less & 78.4 & 74.1 & 83.2 \\
Do not know/ refuse to answer & 17.0 & 21.0 & 12.4
\end{tabular}

\section{C: Risk Question}

Correct (false)

61.8

56.8

67.6

Incorrect (true)

5.9

5.2

6.6

Do not know/ refuse to answer

32.3

38.0

25.8

\section{D: Cross-question Consistency}

Interest \& Inflation

All correct

None correct

At least 1 do-not-know/ refuse

All do-not-know/ refuse

\# Observations
71.9

53.2

10.3

37.0

8.4

68.1

47.5

11.5

43.3

9.7

553

76.3

59.6

8.9

29.9

6.9

Note: Distributions of responses to financial literacy questions in full sample and for female and male respondents. All figures are weighted. 
Table 2: Linear Probability Model: Dependent Variable "3 Answers Correct"

\section{Panel A: US Financial Capability Survey}

(1) (2)

Female

$-0.158 * * *$

$-0.146 * * *$

$(0.0247)$

(0.0242)
(3)

$-0.145 * * *$

(4)

(5)

(0.0240)

$-0.152 * * *$

$-0.138 * * *$

(0.0228)

(0.0228)

Marital

$\mathrm{X}$

X

$\mathrm{X}$

$\mathrm{X}$

Status

Age

$\mathrm{X}$

Education

Income

Observations

1,488

1,488

1,488

0.065

0.086

$\mathrm{X}$

$\mathrm{x}$

$\mathrm{x} \quad \mathrm{X}$

R2

0.03

Panel B: Netherlands DNB Panel

Female

$-0.201 * * *$

$-0.199 * * *$

$-0.204 * * *$

(0.0294)

(0.0298)

$-0.197 * * *$

(0.0290)

$-0.116^{* * *}$

Marital

$$
\text { (0.0294) }
$$

$\mathrm{X}$

$\mathrm{X}$

$\mathrm{X}$

$(0.0342)$

Status

Age

$\begin{array}{lll}\mathrm{x} & \mathrm{x}\end{array}$

Education

$\mathrm{X}$

$\mathrm{x}$

Income

\begin{tabular}{|c|c|c|c|c|c|}
\hline Income & & & & & $\mathrm{X}$ \\
\hline Observations & 1,665 & 1,665 & 1,665 & 1,665 & 1,665 \\
\hline $\mathrm{R} 2$ & 0.041 & 0.042 & 0.051 & 0.098 & 0.126 \\
\hline \multicolumn{6}{|c|}{ Panel C: Germany SAVE survey } \\
\hline Female & $\begin{array}{l}-0.115^{* * *} \\
(0.031)\end{array}$ & $\begin{array}{l}-0.096 * * * \\
(0.031)\end{array}$ & $\begin{array}{l}-0.116^{* * *} \\
(0.032)\end{array}$ & $\begin{array}{l}-0.059 * \\
(0.032)\end{array}$ & $\begin{array}{l}-0.066^{* *} \\
(0.031)\end{array}$ \\
\hline $\begin{array}{l}\text { Marital } \\
\text { Status }\end{array}$ & & $\mathrm{x}$ & $\mathrm{x}$ & $\mathrm{x}$ & $\mathrm{x}$ \\
\hline Age & & & $\mathrm{x}$ & $\mathrm{x}$ & $\mathrm{x}$ \\
\hline Education & & & & $\mathrm{x}$ & $\mathrm{x}$ \\
\hline Income & & & & & $\mathrm{x}$ \\
\hline Observations & 1,059 & 1,059 & 1,059 & 1,059 & 1,059 \\
\hline $\mathrm{R} 2$ & 0.013 & 0.027 & 0.037 & 0.11 & 0.141 \\
\hline
\end{tabular}


Table 3: Linear Probability Model: Dependent Variable "At Least One Do-Not-Know" Panel A: US Financial Capability Survey

(1) (2)

Female

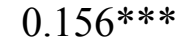

$(0.0272)$

$0.140 * * *$

(3)

(4)

$0.139 * * *$

$0.146 * * *$

$0.131 * * *$

(0.0271)

$\mathrm{X}$

(0.0268)

(0.0259)

(0.0261)

Marital Status

Age

$\mathrm{X}$

$\mathrm{X}$

$\mathrm{X}$

$\mathrm{X}$

Education

Income

Observations

1,488

0.025

1,488

0.054

1,488

0.073

1,488

0.137

\begin{tabular}{|c|c|c|c|c|c|}
\hline \multicolumn{6}{|c|}{ Panel B: Netherlands DNB Panel } \\
\hline Female & $\begin{array}{l}0.168 * * * \\
(0.0296)\end{array}$ & $\begin{array}{l}0.162 * * * \\
(0.0297)\end{array}$ & $\begin{array}{l}0.168 * * * \\
(0.0301)\end{array}$ & $\begin{array}{l}0.163 * * * \\
(0.0297)\end{array}$ & $\begin{array}{l}0.0975^{* * *} \\
(0.0342)\end{array}$ \\
\hline Marital Status & & $\mathrm{x}$ & $\mathrm{x}$ & $\mathrm{x}$ & $\mathrm{x}$ \\
\hline Age & & & $\mathrm{x}$ & $\mathrm{x}$ & $\mathrm{x}$ \\
\hline Education & & & & $\mathrm{x}$ & $\mathrm{x}$ \\
\hline Income & & & & & $\mathrm{x}$ \\
\hline Observations & 1,665 & 1,665 & 1,665 & 1,665 & 1,665 \\
\hline $\mathrm{R} 2$ & 0.03 & 0.033 & 0.038 & 0.065 & 0.089 \\
\hline \multicolumn{6}{|c|}{ Panel C: Germany SAVE survey } \\
\hline Female & $\begin{array}{l}0.128 * * * \\
(0.029)\end{array}$ & $\begin{array}{l}0.106^{* * * *} \\
(0.030)\end{array}$ & $\begin{array}{l}0.121^{* * *} \\
(0.030)\end{array}$ & $\begin{array}{l}0.074 * * \\
(0.030)\end{array}$ & $\begin{array}{l}0.081 * * * \\
(0.030)\end{array}$ \\
\hline $\begin{array}{l}\text { Marital } \\
\text { Status }\end{array}$ & & $\mathrm{x}$ & $\mathrm{x}$ & $\mathrm{x}$ & $\mathrm{x}$ \\
\hline Age & & & $\mathrm{x}$ & $\mathrm{x}$ & $\mathrm{x}$ \\
\hline Education & & & & $\mathrm{x}$ & $\mathrm{x}$ \\
\hline Income & & & & & $\mathrm{x}$ \\
\hline Observations & 1,059 & 1,059 & 1,059 & 1,059 & 1,059 \\
\hline $\mathrm{R} 2$ & 0.018 & 0.039 & 0.047 & 0.099 & 0.131 \\
\hline
\end{tabular}


Table 4: Distribution of responses to financial literacy questions by marital status among women and men

\begin{tabular}{|c|c|c|c|c|c|}
\hline \multicolumn{6}{|c|}{ Panel A: US Financial Capability Study } \\
\hline \multicolumn{3}{|c|}{ Women } & \multicolumn{3}{|c|}{ Men } \\
\hline $\begin{array}{l}\text { marital status } \\
\text { (relative } \\
\text { frequency) }\end{array}$ & $\% 3$ correct & $\begin{array}{l}\% \text { at least } 1 \text { do } \\
\text { not know }\end{array}$ & $\begin{array}{l}\text { marital status } \\
\text { (relative } \\
\text { frequency) }\end{array}$ & $\% 3$ correct & $\begin{array}{l}\% \text { at least } 1 \text { do } \\
\text { not know }\end{array}$ \\
\hline $\begin{array}{l}\text { Married } \\
(51.1 \%)\end{array}$ & 27.7 & 41.6 & $\begin{array}{l}\text { Married } \\
(58.9 \%)\end{array}$ & 47.7 & 27.8 \\
\hline $\begin{array}{l}\text { Single } \\
(25.7 \%)\end{array}$ & 13.4 & 57.4 & $\begin{array}{l}\text { Single } \\
(25.6 \%)\end{array}$ & 23.5 & 43.1 \\
\hline $\begin{array}{l}\text { Divorced } \\
(12.2 \%)\end{array}$ & 24.4 & 58.0 & $\begin{array}{l}\text { Divorced } \\
(11.0 \%)\end{array}$ & 29.6 & 40.7 \\
\hline $\begin{array}{l}\text { Widowed } \\
(11.0 \%)\end{array}$ & 17.1 & 62.3 & $\begin{array}{l}\text { Widowed } \\
(4.6 \%)\end{array}$ & 21.4 & 54.1 \\
\hline Observations & 768 & & & 720 & \\
\hline \multicolumn{6}{|c|}{ Panel B: Netherlands DNB Panel } \\
\hline \multicolumn{3}{|c|}{ Women } & \multicolumn{3}{|c|}{ Men } \\
\hline $\begin{array}{l}\text { marital status } \\
\text { (relative } \\
\text { frequency) }\end{array}$ & $\% 3$ correct & $\begin{array}{l}\% \text { at least } 1 \text { do } \\
\text { not know }\end{array}$ & $\begin{array}{l}\text { marital status } \\
\text { (relative } \\
\text { frequency) }\end{array}$ & $\% 3$ correct & $\begin{array}{l}\% \text { at least } 1 \text { do } \\
\text { not know }\end{array}$ \\
\hline $\begin{array}{l}\text { Married } \\
(67.9 \%)\end{array}$ & 35.2 & 43.5 & $\begin{array}{l}\text { Married } \\
(77.9 \%)\end{array}$ & 56.7 & 28.5 \\
\hline \begin{tabular}{|l} 
Single \\
$(14.0 \%)$
\end{tabular} & 43.8 & 48.2 & $\begin{array}{l}\text { Single } \\
(15.6 \%)\end{array}$ & 53.7 & 33.9 \\
\hline $\begin{array}{l}\text { Divorced } \\
(10.7 \%)\end{array}$ & 21.6 & 57.3 & $\begin{array}{l}\text { Divorced } \\
(3.7 \%)\end{array}$ & 56.1 & 36.1 \\
\hline $\begin{array}{l}\text { Widowed } \\
(7.3 \%)\end{array}$ & 25.6 & 48.0 & $\begin{array}{l}\text { Widowed } \\
(2.8 \%)\end{array}$ & 61.5 & 32.5 \\
\hline Observations & 656 & & & 685 & \\
\hline \multicolumn{6}{|c|}{ Panel C: Germany SAVE Survey } \\
\hline \multicolumn{3}{|c|}{ Women } & \multicolumn{3}{|c|}{ Men } \\
\hline $\begin{array}{l}\text { marital status } \\
\text { (relative } \\
\text { frequency) }\end{array}$ & $\% 3$ correct & $\begin{array}{l}\% \text { at least } 1 \text { do } \\
\text { not know }\end{array}$ & $\begin{array}{l}\text { marital status } \\
\text { (relative } \\
\text { frequency) }\end{array}$ & $\% 3$ correct & $\begin{array}{l}\% \text { at least } 1 \mathrm{do} \\
\text { not know }\end{array}$ \\
\hline $\begin{array}{l}\text { Married } \\
(55.5 \%)\end{array}$ & 51.6 & 40.0 & $\begin{array}{l}\text { Married } \\
(59.3 \%)\end{array}$ & 60.6 & 28.0 \\
\hline $\begin{array}{l}\text { Single } \\
(14.9 \%)\end{array}$ & 47.4 & 40.7 & $\begin{array}{l}\text { Single } \\
(26.1 \%)\end{array}$ & 62.2 & 28.1 \\
\hline $\begin{array}{l}\text { Divorced } \\
(15.4 \%)\end{array}$ & 49.9 & 38.0 & $\begin{array}{l}\text { Divorced } \\
(9.2 \%)\end{array}$ & 52.6 & 38.8 \\
\hline $\begin{array}{l}\text { Widowed } \\
(14.2 \%)\end{array}$ & 28.7 & 64.5 & $\begin{array}{l}\text { Widowed } \\
(5.4 \%)\end{array}$ & 48.8 & 44.4 \\
\hline Observations & 553 & & & 506 & \\
\hline
\end{tabular}


Table 5: Distribution of responses to financial literacy questions by financial decision maker among women and men

\begin{tabular}{|c|c|c|c|c|c|}
\hline \multicolumn{6}{|c|}{ Panel A: US Financial Capability Study } \\
\hline \multicolumn{3}{|c|}{ Women } & \multicolumn{3}{|c|}{ Men } \\
\hline $\begin{array}{l}\text { Financial } \\
\text { decision maker } \\
\text { (relative } \\
\text { frequency) }\end{array}$ & $\begin{array}{l}\% \\
3 \text { correct }\end{array}$ & $\begin{array}{l}\% \text { at least } 1 \text { do } \\
\text { not know }\end{array}$ & $\begin{array}{l}\text { Financial decision } \\
\text { maker } \\
\text { (relative } \\
\text { frequency) }\end{array}$ & $\begin{array}{l}\% \\
3 \\
\text { correct }\end{array}$ & $\begin{array}{l}\% \text { at least } 1 \text { do } \\
\text { not know }\end{array}$ \\
\hline $\begin{array}{l}\text { Sole with partner } \\
(32.5 \%)\end{array}$ & 20.8 & 47.0 & $\begin{array}{l}\text { Sole with partner } \\
(49.0 \%)\end{array}$ & 52.3 & 23.1 \\
\hline $\begin{array}{l}\text { Sole w/o partner } \\
(1.6 \%)\end{array}$ & 34.7 & 45.4 & $\begin{array}{l}\text { Sole w/o partner } \\
(2.3 \%)\end{array}$ & 47.0 & 11.1 \\
\hline $\begin{array}{l}\text { Partner decides } \\
(20.7 \%)\end{array}$ & 19.6 & 44.9 & $\begin{array}{l}\text { Partner decides } \\
(13.1 \%)\end{array}$ & 34.4 & 44.0 \\
\hline $\begin{array}{l}\text { Joint decisions } \\
(44.4 \%)\end{array}$ & 32.9 & 38.9 & $\begin{array}{l}\text { Joint decisions } \\
(34.9 \%)\end{array}$ & 43.6 & 28.5 \\
\hline Observations & 436 & & Observations & 464 & \\
\hline \multicolumn{6}{|c|}{ Panel B: Netherlands DNB Panel } \\
\hline \multicolumn{3}{|c|}{ Women } & \multicolumn{3}{|c|}{ Men } \\
\hline $\begin{array}{l}\text { Financial } \\
\text { decision maker } \\
\text { (relative } \\
\text { frequency) }\end{array}$ & $\begin{array}{l}\% \\
3 \text { correct }\end{array}$ & $\begin{array}{l}\% \text { at least } 1 \text { do } \\
\text { not know }\end{array}$ & $\begin{array}{l}\text { Financial decision } \\
\text { maker } \\
\text { (relative } \\
\text { frequency) }\end{array}$ & $\begin{array}{l}\% \\
3 \\
\text { correct }\end{array}$ & $\begin{array}{l}\% \text { at least } 1 \text { do } \\
\text { not know }\end{array}$ \\
\hline $\begin{array}{l}\text { Sole with partner } \\
(8.4 \%)\end{array}$ & 21.5 & 63.9 & $\begin{array}{l}\text { Sole with partner } \\
(16.5 \%)\end{array}$ & 65.0 & 23.3 \\
\hline $\begin{array}{l}\text { Sole w/o partner } \\
(34.1 \%)\end{array}$ & 37.3 & 47.7 & $\begin{array}{l}\text { Sole w/o partner } \\
(22.6 \%)\end{array}$ & 55.5 & 33.7 \\
\hline $\begin{array}{l}\text { Partner decides } \\
(10.2 \%)\end{array}$ & 40.8 & 38.3 & $\begin{array}{l}\text { Partner decides } \\
(8.0 \%)\end{array}$ & 26.0 & 48.4 \\
\hline $\begin{array}{l}\text { Joint decisions } \\
(47.3 \%)\end{array}$ & 35.4 & 44.8 & $\begin{array}{l}\text { Joint decisions } \\
(52.9 \%)\end{array}$ & 54.9 & 28.6 \\
\hline Observations & 662 & & Observations & 656 & \\
\hline \multicolumn{6}{|c|}{ Panel C: Germany SAVE Survey } \\
\hline \multicolumn{3}{|c|}{ Women } & \multicolumn{3}{|c|}{ Men } \\
\hline $\begin{array}{l}\text { Financial } \\
\text { decision maker } \\
\text { (relative } \\
\text { frequency) }\end{array}$ & $\begin{array}{l}\% \\
3 \text { correct }\end{array}$ & $\begin{array}{l}\% \text { at least } 1 \text { do } \\
\text { not know }\end{array}$ & $\begin{array}{l}\text { Financial decision } \\
\text { maker } \\
\text { (relative } \\
\text { frequency) }\end{array}$ & $\begin{array}{l}\% \\
3 \\
\text { correct }\end{array}$ & $\begin{array}{l}\% \text { at least } 1 \text { do } \\
\text { not know }\end{array}$ \\
\hline $\begin{array}{l}\text { Sole with partner } \\
(5.9 \%)\end{array}$ & 53.8 & 29.4 & $\begin{array}{l}\text { Sole with partner } \\
(6.5 \%)\end{array}$ & 67.8 & 25.2 \\
\hline $\begin{array}{l}\text { Sole w/o partner } \\
(39.1 \%)\end{array}$ & 40.4 & 50.4 & $\begin{array}{l}\text { Sole w/o partner } \\
(36.1 \%)\end{array}$ & 54.5 & 35.3 \\
\hline $\begin{array}{l}\text { Partner decides } \\
(2.6 \%)\end{array}$ & 57.1 & 30.1 & $\begin{array}{l}\text { Partner decides } \\
(2.8 \%)\end{array}$ & 54.2 & 25.5 \\
\hline $\begin{array}{l}\text { Joint decisions } \\
(52.4 \%)\end{array}$ & 51.6 & 40.2 & $\begin{array}{l}\text { Joint decisions } \\
(54.6 \%)\end{array}$ & 62.4 & 27.2 \\
\hline Observations & 553 & & Observations & 506 & \\
\hline
\end{tabular}


Table 6: Financial Advice by Gender and Financial Literacy

Panel A: Netherlands DNB Panel

No Personal Advice Formal Advice Informal Advice

By By Family And Friends

Professionals

$\begin{array}{llll}\text { All }(\mathrm{N}=1,392) & 52.2 & 23.1 & 24.7\end{array}$

By gender

\begin{tabular}{|llll}
\hline Women $(\mathrm{N}=694)$ & 46.6 & 23.4 & 29.9 \\
\hline Men $(\mathrm{N}=698)$ & 57.8 & 22.8 & 19.4
\end{tabular}

By financial literacy

\begin{tabular}{|lccc|}
\hline $\begin{array}{l}3 \text { answers correct } \\
(\mathrm{N}=631)\end{array}$ & 55.3 & 25.9 & 18.9 \\
\hline $\begin{array}{l}\text { At least one do-not- } \\
\text { know }(\mathrm{N}=526)\end{array}$ & 47.1 & 21.1 & 31.8
\end{tabular}

Panel B: Germany SAVE survey

\begin{tabular}{|lcll|}
\hline & No Personal Advice & $\begin{array}{l}\text { Formal Advice } \\
\text { By } \\
\text { Professionals }\end{array}$ & $\begin{array}{l}\text { Informal Advice } \\
\text { By Family And Friends }\end{array}$ \\
\hline All $(\mathrm{N}=1,059)$ & 33.5 & 33.1 & 48.8 \\
\hline & & By gender & \\
\hline Women $(\mathrm{N}=553)$ & 30.3 & 31.4 & 53.0 \\
\hline Men $(\mathrm{N}=506)$ & 37.2 & 35.0 & 44.0 \\
\hline & & By financial literacy & \\
\hline $\begin{array}{l}3 \text { answers correct } \\
(\mathrm{N}=560)\end{array}$ & 26.5 & 40.1 & 55.1 \\
\hline $\begin{array}{l}\text { At least one do-not- } \\
\text { know (N=391) }\end{array}$ & 43.2 & 23.4 & 41.1 \\
\hline
\end{tabular}

